\title{
ИНТЕРПРЕТАЦИОННАЯ ОБРАБОТКА СЕЙСМИЧЕСКИХ ДАННЫХ С ЦЕЛЬЮ ВЫЯВЛЕНИЯ ПЕРСПЕКТИВНЫХ НА НЕФТЬ И ГАЗ ОБЪЕКТОВ НА ПРИМЕРЕ МАТЕРИАЛОВ ОБСКО- ТАЗОВСКОГО МЕЛКОВОДЬЯ.
}

Дергунов Н.Т., Ефимова Н.Н., Рослов Ю.В (ФI'У $H П П \Pi$ "СЕВМOРГЕО»)

Для решения задач выявления перспективных на нефть и газ объектов и локального прогноза аномальных зон типа залежь была применена дополнительная интерпретационная обработка сейсмических записей. Цель данной работы - извлечение из сейсмического материала дополнительных признаков, указывающих на наличие УВ.

Для решения поставленных задач использовались следуюшие методы их решения:

- Апробашия томографического подхода для решения задач прогноза нефтяных и газовых залежей;

- Вычисление по временным и глубинным динамическим разрезам разрезов мгновенныг параметров;

- Опробование волнового аналога метода ОГТ (расчет дифракторов);

- Комплексный анализ волновых полей;

Основная идея применения томографического подхода состояла в разделении структурновещественных комплексов среды по скоростным параметрам. Известно, что скорость продольньх волн в нефтегазонасьщенных породах значительно ниже, чем в водонасыщенных породах, поэтому появляется возможность, использовать зоны аномально низких значений скорости на сейсмотомографическом разрезе для прогноза газовых и нефтяных залежей. Для сейсмотомографической обработки с целью выявления низкоскоростных аномалий использовались сейсмические материалы в пределах Обско-Тазовскогого мелководья

Профили были отработаны с использованием телеметрической системы "BOX", которая обеспечила получение сейсмических записей с больпими удалениями источник - приемник. Такая методика работ позволила достаточно уверенно прослеживать как отраженные, так и преломленные волны и использовать сейсмотомографическую обработку годографов первых и последующих волн при интерпретации сейсмических данных.

Комплексный анализ волновых полей заключался в совместном рассмотрении временных разрезов, разрезов мгновенных параметров (Focus5.3,Paradigm Geophisical), разрезов ВОГТ (разработка ЮНИИТ, Хантымансийск) и скоростньгх томографических разрезов (X-Томо).

Детальный анализ зон аномально низких значений скоростей и сопоставление их с характерными особенностями волновой картины на временных и глубинных разрезах показал, что низкоскоростные аномалия хорошо коррелируются с морфологическими признаками и аномалкями динамических параметров.

На рисунке 1 между отражаюшими горизонтами $\mathrm{I}_{\mathrm{a}}$ и $\mathrm{I}_{6}$ выделяется структурно-литологическая ловушка (выклинивание нижнеюрской толщи) в пределах, которой сейсмотомографий метод выде- ляет низкоскоростную аномалию. В пределах ловушки отмечается уменьшение скорости продольных волн около $20 \%$. Ниже ловушки на разрезе прослеживается зона дифракторов, которая подчеркивает в глубинной части геологидеского разреза область дизьюнктивных нарушений. Эти нарушения хорошо коррелируются с выделяемыми аномальными объектами, залегающими выше и могут связываться с путями миграции УВ.

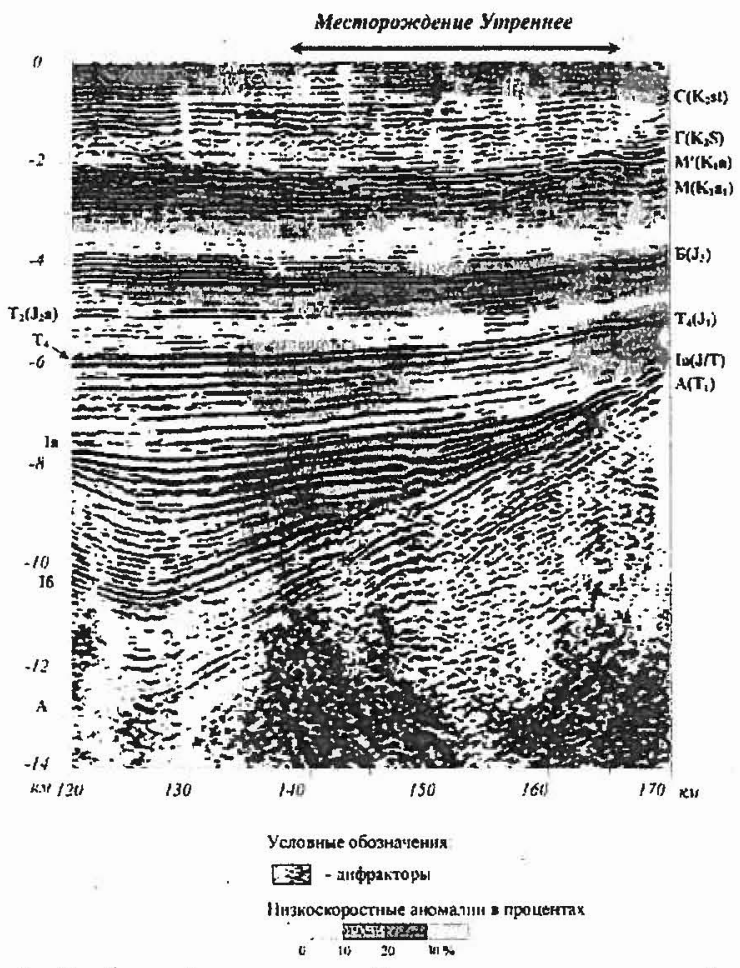

Рнс.1. Глубинный динамический разрез на участке профидя $\mathrm{R} 4$,совмещенный с попученными низкоскоростными аноматиями и дифракторами.

На примере сейсмических материалов, полученных в Обско-тазовском мелководье показана перспективность использования сейсмотомографического подхода для решения задач прогноза нефтяньх и газовыг залежей в качестве дополнительного критерия при комплексном анализе волновых полей. 